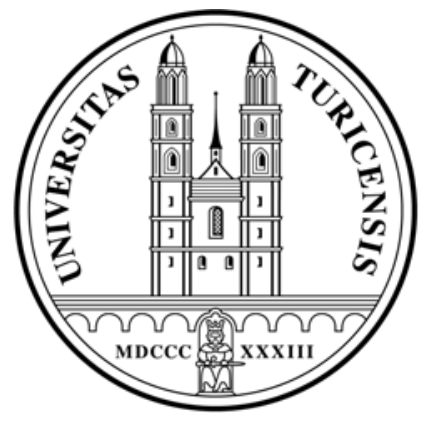

Institute for Empirical Research in Economics

University of Zurich

Working Paper Series

ISSN 1424-0459

Working Paper No. 451

\title{
What is Economics? - Attitudes and views of German economists
}

Bruno S. Frey, Silke Humbert and Friedrich Schneider

October 2009 


\title{
What is Economics? - Attitudes and views of German economists
}

(this version September 30th, 2009)

\author{
Bruno S. Frey, Silke Humbert \\ Institute for Empirical Research in Economics, University of Zurich, Zurich, Switzerland
}

\author{
Friedrich Schneider \\ Department of Economics, Johannes Kepler University of Linz, Linz, Austria
}

Bruno S. Frey is Professor of Economics at the University of Zurich, Institute for Empirical Research in Economics, Winterthurerstr. 30, CH-8006 Zurich, Switzerland, bsfrey@iew.uzh.ch.

Silke Humbert was a Research Assistant at the same Institute, silke.humbert@gmx.de. Friedrich Schneider is Professor of Economics at the University of Linz, Altenbergerstr. 69, A-4040 Linz, friedrich.schneider@jku.at.

Frey and Schneider are also associated with CREMA - Center for Research in Economics, Management and the Arts, Switzerland.

\begin{abstract}
Which schools of thought are favored by German economists? What makes a good economist and which economists have been most influential? These questions were addressed in a survey, conducted in the summer of 2006 among the members of the 'Verein für Socialpolitik', the association of German speaking economists. An econometric analysis is used to identify to what extent ideological preferences or personal factors determine the respondents' answers. Our results suggest that German economists favor Neoclassics as a school of thought and appreciate the contributions of their Anglo-Saxon colleagues much more than their fellow compatriots' contributions. Furthermore, a 'good' economist should have expertise in a certain field, as well as a broader knowledge of general economics. Some of the results can be compared to Colander (2008). The results indicate that graduate programs noted for their American style greatly influence a student's opinion as to what attributes a good economist must have.
\end{abstract}

JEL-Classification: economics; economists; school of thought; neoclassics; homo oeconomicus 


\section{Introduction}

Which schools of thought are favored by German economists? Are economists more influenced by a single and outstanding economist or rather by predominant schools of thought? What makes a good economist?

These questions were addressed in a survey conducted in the summer of 2006 among the members of the Association of German-speaking Economists ("Verein für Socialpolitik"). The old-established Association - founded back in 1873 - is the only association of its kind in the German-speaking countries; it has roughly 3400 members. This article focuses on questions providing insights into German economists' views on economics and economists. The results are compared to a very recent study by Colander (2008) among European graduate students in economics. In this study, only graduate students at top European universities, that offer a graduate economics program similar to the US graduate programs, were taken into account. This allows us to reflect on changes in attitudes that are likely to take place among German economists as American graduate programs gain ground in Europe.

Economists usually take a sceptical view towards the results of surveys. A low return rate, problems of self-selection and the uncertainty about the identity of the respondents are typical problems to be faced when evaluating surveys. Asking respondents to use pre-set answer categories generates a framing problem - the respondent's initial view might not be among the possible answers given. Moreover, the answers will only reflect what respondents will advance to be thinking. What they really think or how they would act might be a different story. Nonetheless, we believe that if surveys are inter- 
preted with caution, they are a good and efficient way to give a first impression on particular topics.

The literature on surveys about economics as a discipline we refer to, can roughly be divided in three groups. Surveys that focus on the nature of American graduate programs $^{1}$, articles that focus on an European perspective and compare it to the United States $^{2}$ and articles that study and comment the extent of disagreement among economists $^{3}$. The substantial contribution of our work is that we outline the current views and attitudes of German economists on the reigning paradigm in the discipline, the role of individuals in the discipline and the key characteristics of success in the discipline. The results serve to give an impression about German economists and about the current state of the discipline. In addition, comparisons to similar surveys among Americans identify differences across the Atlantic.

In Part 2, we discuss the data gathered. Part 3 deals with the scientific orientation of German economists and the approaches favored by them. Part 4 examines the importance of famous economists as role models and the influence attributed to leading economists. In Part 5, the criteria of a good economist among German economists and European graduate students are discussed. Chapter 6 concludes.

\section{Data}

The composition of the Association of German-speaking economists ("Verein für Socialpolitik") is well represented in the sample, which consists largely of scientifically orientated members (36\% professors and $44 \%$ other scholars) and to a smaller extent of economists not engaged in research (7\% working in public service and 13\% working in pri- 
vate industry). Slightly more than half of the economists in the sample are 35-55 years old, almost a third are younger than 35 , and the rest are older than 55 . The majority $(87 \%)$ are males.

All 2647 members of the Association living in Germany were asked to fill in an Internet-questionnaire. The response rate was $22 \%$. The answers given to the questions were analyzed according to the respondent's profession, age, gender and ideology. To distinguish between these different influences, a multiple probit analysis was undertaken. Detailed results can be found in the Appendix.

\section{Schools of thought}

Table 1 shows the responses to the question as to which school of economic thought is preferred.

Table 1 about here

The answers identify Neoclassical Theory as the predominant school of thought among German economists, closely followed by Public Choice/Institutional Economy. Ordo-Liberalism, a specifically German version of free-market thinking, strongly shaped by Walter Eucken in the 1940s and 1950s, is somewhat less popular, but still clearly preferred to other schools of thought, such as Keynesianism or Supply Side Economics. Hardly any German economist today includes a left-wing ideology (Socialism/Marxism) in his or her favorite approach.

A multiple probit analysis (see Appendix) of the determinants of the answers given reveals that economists working at universities or research institutions are more in favor of Neoclassical Theory than their colleagues in private industries or public services. 
Liberal-minded economists prefer Ordo-Liberalism and Supply Side Economics and rate Keynesianism much lower than their colleagues. The multiple probit analysis exhibits that Ordo-Liberalism is also more appreciated by older economists, aged over 55, which can be explained by the fact that some of them were taught by teachers of an Ordo-liberal orientation. In contrast, younger economists (under age 35) reveal a preference for Supply Side Economics.

The authors of the survey suggested the schools of thought presented in Table 1. There was also the possibility of stating a school of thought not presented in the survey, and about $8 \%$ of the respondents made use of that. They noted alternative schools, such as evolutionary economics (13 entries), behavioral economics ( 3 entries), ecological economics ( 2 entries) and a few others. This corresponds to Mueller (2004) who identifies behavioral and evolutionary economics as the two promising new approaches that can contribute to the study of human behavior.

Table 2 focuses on whether Neoclassical Theory is accepted by German economists.

\section{Table 2 about here}

Neoclassical Theory receives a lot of support, with $80 \%$ of German Economists agreeing fully, or with certain provisions. The support of Neoclassical Theory strongly declines with age.

The evaluation of Neoclassical Theory seems to be somewhat different in the United States. American graduate students in the early 1980s considered it to be more 
relevant than Europeans, twenty years later they valued Neoclassical Theory even more (Colander 2007).

The model of man used is closely related to the theory supported. The utility maximizing and (generally) self-interested homo oeconomicus is a central part of Neoclassical Theory. Table 3 shows whether this model is accepted or rejected by the German economists' responses.

\section{Table 3 about here}

A large majority of $67 \%$ completely disagrees or disagrees with provisions to the statement that the homo oeconomicus is a distorted picture of reality and therefore useless. The multiple probit analysis reveals that younger and older economists tend to reject the utility maximizing agent to a larger extent than their middle-aged colleagues. This finding may be explained in various ways. Young economists are less prepared to accept the homo oeconomicus, because they are more aware of recent developments in psychological economics (often misleadingly called 'behavioural economics' and game theory). Consistent with the answers to the previous question in Table 2, a large number of older economists have never accepted Neoclassics and its model of man, but remain committed to other approaches (see Table 1). Generally, the homo oeconomicus seems to be contradictory to other models of individual human behavior. Attempts to find a generally accepted model of man and to unify the human behavioral sciences, as in Gintis (2004), are rare. 
German Economists were also asked whether they consider their research to be mainly empirically orientated, mainly theoretically oriented (i.e. pure research), or aiming at policy advice.

\section{Table 4 about here}

Table 4 indicates that although $80 \%$ of the respondents are researchers at a University or research institution, only $34 \%$ consider their research to be mainly theoretically oriented. $66 \%$ of the respondents state that they are mostly concerned with empirical research or aim to give policy advice. The question may have been somewhat misleading, as the terms "empirical" or "theoretical" were not defined, and the respondents may have interpreted them quite differently.

Do economists believe that there is consensus about what their discipline constitutes? According to Table 5, this does not seem to be the case. More than $40 \%$ of economists in Germany do not think that there is agreement on the major issues. Taking a closer look, scholars at universities and research institutions believe that there is agreement on fundamental issues. This suggests that views on general economic topics are quite homogenous inside the university but start to broaden and become manifold outside the university.

\section{Table 5 about here}

In contrast, Colander and Klamer (1987), Colander (2005) and Colander (2008) show that European and American graduate students rate the agreement on fundamental 
issues much lower than German economists. They even notice a slight drop in assumed agreement after students have entered graduate school, which questions the hypothesis of uniform opinion inside the university. Van Dalen and Klamer (1997) show that Dutch graduates observe more disagreement among their colleagues at graduate school than German economists of all ages do. Due to a standardized curriculum, however, we would have expected more agreement among university scholars. One explanation of these findings might be that students, studying lots of different theories in a short time, don't see the wood for the trees. Older economists might be in a better position to sort out fancy new ideas from fundamental issues. Colander's (2007) results seem to confirm this idea: The respondents of his survey, while enrolled in an American graduate program in the 1980s, see very little agreement on fundamental issues among their colleagues. In contrast twenty years later the same respondents see more agreement among their fellow colleagues than the German economists.

While the surveys presented so far examine disagreement indirectly, by looking at a participant's assumptions about disagreement among economists in general, the studies conducted by Alston, Kearl and Vaughan (1992) and Kearl, Pope, Whiting and Wimmer (1979) among members of the American Economic Association explore agreement on specific issues directly by posing concrete questions on content. They conclude that there is considerable consensus among American economists, especially on microeconomic issues, while normative and macro-economic issues tend to generate more disagreement.

It should also be kept in mind that economists have different things in mind when faced with the term "fundamental issues". Colander (1994) complains that the discussion is not focussed on "fundamental issues" such as widely accepted assumptions, but rather 
on petty disagreements over minor issues. In his article "How to do well while doing good", Tullock (1984) specifies three rent-seeking activities ${ }^{4}$ as fundamental issues. He assumes that there is clear agreement among economists that a campaign against these activities makes society better off. Schelling (1995) investigates what in economics is true, important and obvious, and discovers accounting identities that haven't always been known to be true.

Moreover, ideology may also influence what are considered fundamental issues. When it comes down to policy issues, things get even more complicated. Since the relation between conventional parameters and policy choices is fairly loose, loyalty to a university or reluctance to read the work of rivals can influence our view on policy issues, as suggested by Mayer (2001). Differences in culture and history, as well as a country's differing current economic and political situations, can lead to disagreement among economists, as pointed out by Frey, Pommerehne, Schneider and Gilbert (1984).

\section{Influence of persons}

Conceptually, the knowledge enshrined in a discipline can be transferred over time in two different ways, either through a person, like a teacher, or more abstractly through written text in the form of books or web content.

\section{Table 6 around here}

Table 6 suggest that the role of academic teachers is seen as significant. $40 \%$ of economists consider themselves to be someone's disciple, and almost half of the respondents admit to having had scientific role models over the course of their scientific career. 
The responses differ markedly with respect to age. Older economists are more ready to acknowledge that a particular person has influenced them personally, while younger economists strongly deny such a personal influence. This age dependency might be attributed to a generational effect. On the one hand, when economists grow older, they become more vividly aware that a particular person has helped shape their knowledge. Older economists have also had more opportunities to encounter someone they perceived as a teacher or a role model in their career. On the other hand, young scholars are especially receptive to forming role models. Therefore, the answers may reflect a tendency for economics to increasingly become an "objective" science, because its content can be transmitted in an impersonal manner, in particular through textbooks. There is, however, the possibility that younger economists are not aware of how they are being shaped by teachers and role models, or that they do not like to admit it.

Table 7 lists the answers German economists gave when specifically asked about the influence on their discipline of a number of famous economists of the (recent) past and present time. Contrary to their estimation on agreement on fundamental issues (Table 5), German economists seem to have similar opinions on whose contribution has been important in shaping today's economy.

\section{Table 7 about here}

The contributions by Samuelson, Keynes, Friedman and Stiglitz are taken to be the most important. A group of economists, comprising Krugman, Becker, von Hayek, Buchanan and Sen, is also greatly appreciated; their contribution is taken to be "very" important or at least "moderately" important by between 68 and 77 percent of the re- 
spondents. It is noteworthy that German economists value Anglo-Saxon economists very highly. Friedrich von Hayek is the only exception, but he is not ranked among the four top economists. It is remarkable and rather surprising that the contribution of Walter Eucken, the founder of Ordo-Liberalism, and Ludwig Erhard, the "father" of the "Soziale Marktwirtschaft" (Social Market Economy) and the German post-war "Wirtschaftswunder", are not very much appreciated by today’s economists.

It is striking to see that the smaller the attributed importance of an economist is, the larger is the number of "don't know"-answers. Two clear exceptions are the only two German economists, Walter Eucken and Ludwig Erhard. Their contribution towards today's economy is taken to be small, but it is not due to them being unknown. In a study by Dalen and Klamer (1997), Dutch economists are asked a similar question about most respected economists. Contrary to German economists, their fellow countryman Jan Tinbergen stands out as the most respected economist, due to his ability to link economic theory with practice. Dalen and Klamer refer to this result as "Blood is thicker than water". For German economists' assessment on important economists, this does not constitute an adequate explanation.

The probit analysis reveals that women appreciate the contributions of Ludwig Erhard and Walter Eucken far more than their male colleagues. As is to be expected, older economists hold Walter Eucken in higher esteem than younger and middle-aged economists. This finding is consistent with the greater appreciation older economists have for Ordo-Liberalism (Table 1).

North, Kahneman, Shleifer and Tirole are not known by at least a fifth of the respondents. Especially among older economists, the contributions of Kahneman, Tirole 
and Debreu are not greatly appreciated. In contrast, Becker and Friedman are very popular with younger economists, which may be due to their innovative contributions.

Scholars at universities or research institutions value the contributions of Samuelson and Debreu more than their colleagues working in private industry or public service. These scholars indeed stand out as leading theoreticians. Contributions by Eucken and Krugman are in turn valued less by scholars at universities or research institutions than by those working in the private sector or public service.

Comparing the relative importance attributed to the works of Eucken and Erhard, and the relative acceptance of the school of thought they founded, suggests that the respective school is more predominant than the individual contribution. With Keynes, the situation is the other way round: His contribution to today's economics is highly appreciated, but the school of thought he founded, and which is named after him, does not find many supporters. Generally individual economist's contributions are often highly appreciated, corresponding schools of thought however much less supported.

\section{What makes a good economist?}

The survey among German economists presented here replicated parts of the inquiry among European graduate students in 2005/6, asking what features a "good economist" should have (Colander, 2008). It was deliberately left to the correspondents to determine what "good" in this context means. The respondents could react to seven specific statements, as seen in Table 8 . 
German economists find specialized knowledge "about a particular field" of greatest importance, followed by a talent for empirical research. A wide knowledge of the economic literature and a thorough knowledge of the economy are taken to be very important by around half of the respondents. Problem solving capabilities are thought to be of lesser importance. Interestingly enough, only one quarter of the respondents sees excellence in mathematics as being very important. Mastering mathematics is far less important than being good at empirical methods. This fits in well with the fact that less than one third of the respondents characterize their work as mainly theoretical (pure research) although $80 \%$ work at universities or research institutions. To base one's career on being well connected with prominent professors is taken to be highly valuable by only 7 percent of the respondents, while 50 percent see it as unimportant.

There are large differences in the perceptions of success between German economists and European graduate students. While "Being very knowledgeable about one particular field" is ranked highest among German economists, European graduate students rank it much lower, with less than half as many respondents considering it to be very important. Highest ranked among European graduate students is "Being smart in the sense of being good at problem solving". Mathematics is seen as very important by $40 \%$ of the European graduate students. Whereas more than half of the German economists find a wide knowledge of the economic literature very important, only every fifth European graduate student considers it to be very important.

The views regarding "A thorough knowledge of the economy" correspond to the above answers. The majority of the European graduate students find it unimportant, while 
almost half of the German economists find it very important. The ability to make connections with prominent professors is regarded as more important among European graduate students than among German economists. Almost one third of the European graduate students find it very important, whereas only $7 \%$ of German economists consider it to be very important.

After carrying out his study on the nature of American graduate programs in the early 1980s, Colander (2007) surveyed the respondents of the original survey again in $2002^{5}$. The respondents, who by then were in their late 30 s and early 40 s, were asked "What puts someone on the fast track in their jobs?" Although the sample size of the former American graduate students is small, the results provide some interesting insights and can (cautiously) be compared to our own survey. ${ }^{6}$ Generally speaking, the answers of the US professionals correlate much more with the answers of the European graduate students (despite the different stages of their careers) than with the answers of the German economists. US professionals rank "being knowledgeable about one particular field", "Being interested in, and good at empirical research" and "Being smart in the sense of being good at problem-solving" as important as do European graduate students. Thus, "Being very knowledgeable about one particular field" which was ranked highest by German economists is seen as much less important by European graduate students and US professionals, whereas "Being smart in the sense of being good at problem-solving" is a more important key factor for success in their opinion. 


\section{Discussions}

The answers given by the European graduate students very much resemble the answers given by the American graduate students in the study by Colander and Klamer (1987). This is not surprising, since the criteria for choosing the European graduate students was their attendance in a graduate program similar to the graduate programs in the $\mathrm{US}^{7}$. The results of the study by Colander and Klamer alerted the scientific community. Frey and Eichenberger (1992) stated that "The criterion for survival has very little to do with how well the real world is explained, but very much with how capable one is of formalizing and logically advancing the reigning paradigm, neoclassics; that is, technique is what matters." Kolm (1988) argued that the new success criteria were "whether an author is able to solve classroom exercises and nice little games". Zevin (1992) generally misses the ability to produce value judgments among American graduate students.

Evidence seems to suggest that the effect of US type graduate programs on European students is very similar to the effect these programs have on American students: problem solving becomes the dominant success factor and seems to replace interests that are not of direct use in upcoming examinations. Certainly, there is no doubt that students are always more focused on problem solving than economists outside academia. Doubtlessly too, European economics is growing together and the country-specific characteristics might partially be replaced by a harmonized European economics. However, the extent of differences between European graduate students and German economists regarding their estimation of what it takes to be a good economist suggests the American graduate program has a strong influence on European students. Van Dalen and Klamer (1997) further confirm this idea: They show that Dutch students generally value a thorough 
knowledge of the economy and broad knowledge of the economic literature and are not too much focused on problem solving ${ }^{8}$. However, Dutch students in PhD programs modeled on American $\mathrm{PhD}$ programs are strongly biased to problem solving and resemble American graduates in their answers. The importance US professionals attribute to problem solving abilities further suggests that for US economists problem solving is the most important key factor no matter at what stage their careers are (Colander 2007).

It is however still an open question whether the influence of American graduate programs is a permanent one or if work experience in Europe after graduate school will eventually replace this influence. A follow-up study among former European graduate students now working in Europe - similar to the follow-up study Colander did with American graduate students - could shed light on these questions. Nonetheless, our study gives evidence that the views and attitudes of German economists are not set in stone: younger economists seem to be influenced much less by teachers and role models; also Neoclassical Theory is appreciated more strongly among young economists - both trends show that German economists might be brought closer to US economists.

It is an interesting finding that European students' perceptions of success factors are closer to US professional economists than to German professional economists. American graduate programs thus seem to crowd out specific cultural characteristics. Colander (2008) even finds that the differences among American students in different graduate programs are sometimes larger than the differences between American and European graduates. But if economics is a pure science - as is often claimed - isn't the harmonization of economics on either side of the Atlantic Ocean an inevitable consequence? Forte (1995) argues that economics is not merely a science - it is a social science 
and, as such, it needs to consider the specific context. For this reason, the existence of an European economics is necessary. Frey and Eichenberger (1993) suggest that European markets for economists are different from American markets. European markets are smaller and economists need more hands-on policy skills. Colander (2008) favors the fact that "European academic researchers have not had the strong focus on journal publication that US researchers have had". After all, he says, “journal publications are not necessarily a good proxy for important research ideas". He, too, thinks that the institutional structure and the job market in Europe and the US differ, and therefore advises against copying American graduate programs on European territory.

The influence of American graduate programs are likely to increase in the years to come, since they "represent the likely future of graduate economic education in Europe" (Colander, 2008). Already today European students' perception of success factors is closer to US professional economists than to German professional economists. As a result, local political and economic conditions become less important. So maybe we should not stop with the question "What is Economics?", but go on to ask ourselves "What will Economics be?" or, more importantly, "How do we want Economics to be?" While this last question is essential, it goes beyond this paper's aim, which is to provide factual information of what economists in Germany think. 


\section{References}

Alston, Richard M., James R. Kearl and Michael B. Vaughan (1992). 'Is There a Consensus Among Economists in the 1990's?' American Economic Review 82(2): 203-209.

Colander, D. (1994), 'Vision, Judgement, and Disagreement among Economists', Journal of Economic Methodology, 1(1), 43-56.

Colander, D. (2005), 'The Making of an Economist Redux', Journal of Economic Perspectives, 19(1), 175-198.

Colander, D. (2007), The Making of an Economist Redux, Princeton: Princeton University Press.

Colander, D. (2008), 'The Making of a Global European Economist', Kyklos, 61(2), 215236.

Colander, D., and Klamer, A. (1987), 'The Making of an Economist', Journal of Economic Perspectives, 1(2), 95-111.

Dalen, H.P. van, and Klamer, A. (1997), 'Blood Is Thicker than Water: Economists and the Tinbergen Legacy', in Economic Science and Practice, eds. P.A.G. van Bergeijk, A. L. Bovenberg, E.E.C. van Damme, and J. van Sinderen, Cheltenham, UK and Lyme, US: Edward Elgar.

Forte, F. (1995) 'European Economics: A Tiny Creature under Tutorship', Kyklos, 48(2), 211-217.

Frey, B.S., and Eichenberger, R. (1992), 'Economics and Economists: A European Perspective', American Economic Review, 82(2), 216-220. 
Frey, B.S., and Eichenberger, R. (1993), 'American and European Economics and Economists', Journal of Economic Perspectives, 7(4), 185-193.

Frey, B.S., Humbert, S., and Schneider, F. (2007), 'Was denken deutsche Ökonomen? Eine empirische Auswertung einer Internetbefragung unter den Mitgliedern des Vereins für Socialpolitik im Sommer 2006', Perspektiven der Wirtschaftspolitik, 8(4), 359-377.

Frey, B.S., Pommerehne, W.W., Schneider, F., and Gilbert, G. (1984), 'Consensus and Dissension among Economists: An Empirical Enquiry', American Economic Review, 74(5), 986-994.

Gintis, H. (2004), 'Towards the Unity of the Human Behavioral Sciences', Politics, Philosophy and Economics, 3(1), 37-57.

Hansen, W.L. (1991), 'The Education and Training of Economics Doctorales: Major Findings of the Executive Secretary of the American Economic Association's Commission on Graduate Education in Economics', Journal of Economic Literature, 29(3), 10541087.

Kearl, J.R., Clayne L.P., Gordon C.W., and Larry T.W. (1979), 'A Confusion of Economists?', American Economic Review, 69(2), 28-37.

Klamer, A., and Colander D. (1990), The Making of an Economist, Boulder, Co.: Westview Press.

Kolm, S.-C. (1988), 'Economics in Europe and in the U.S.', European Economic Review, $32(1), 207-212$.

Krueger, A.O. (1991), 'Report of the Commission on Graduate Education in Economics', Journal of Economic Literature, 29(3), 1035-1053. 
Mayer, T. (2001), 'The Role of Ideology in Disagreements among Economists: A Quantitative Analysis', Journal of Economic Methodology, 8(2), 253-273.

Mueller, D.C. (2004), 'Models of Man: Neoclassical, Behavioural, and Evolutionary', Politics, Philosophy and Economics, 3(1), 59-76.

Schelling, T.C. (1995). 'What Do Economists Know?', American Economist, 39(1), 2022.

Tullock, G. (1984), 'How to Do Well While Doing Good!', in Neoclassical Political Economy: The Analysis of Rent-seeking and DUP Activities, ed. D.C. Colander, Cambridge, MA: Harper \& Row, Ballinger.

Zevin, R.B. (1992), 'Economists, Judgment, and Business', in Educating Economists, eds. D. Colander, and R. Brenner, Ann Arbor: University of Michigan Press. 
Table 1. Schools of thought

Considering your scientific attitudes and orientation, which $\quad$ Yes [\%] school of thought do you prefer?

\begin{tabular}{ll} 
Neoclassical Theory & 42 \\
Public Choice/Institutional Economy & 37 \\
Ordo-Liberalism & 24 \\
Keynesianism & 12 \\
Supply Side Economics & 7 \\
Monetarism & 5 \\
Socialism/Marxism & 1 \\
\hline
\end{tabular}

Note: Table 1 shows the answers of the German economists to the question above. Multiple answers were possible. The predominant school among German economists is Neoclassical Theory, closely followed by Public Choice/Institutional Economy.

Table 2. Neoclassical Theory

\begin{tabular}{|c|c|c|c|c|c|}
\hline & $\begin{array}{l}\text { Generally } \\
\text { Agree [\%] }\end{array}$ & $\begin{array}{l}\text { Agree with } \\
\text { certain Pro- } \\
\text { visions [\%] }\end{array}$ & $\begin{array}{l}\text { Generally } \\
\text { Disagree } \\
{[\%]}\end{array}$ & & $\begin{array}{l}\text { No Answer } \\
{[\%]}\end{array}$ \\
\hline $\begin{array}{l}\text { Neoclassical Theory is im- } \\
\text { portant for the solution of } \\
\text { current political and eco- } \\
\text { nomic problems. }\end{array}$ & 30 & 50 & & 17 & 2 \\
\hline
\end{tabular}

Table 2 shows the respondents' views on the importance of Neoclassical Theory. There is little doubt that Neoclassical Theory still looms large among German Economists.

Table 3. Homo oeconomicus

\begin{tabular}{lllll} 
Generally & $\begin{array}{l}\text { Agree } \\
\text { with Pro- }\end{array}$ & $\begin{array}{l}\text { Disagree } \\
\text { with Pro- }\end{array}$ & $\begin{array}{l}\text { Generally } \\
\text { Disagree }\end{array}$ & No An- \\
Agree & visions & visions & Dio] \\
{$[\%]$} & {$[\%]$} & {$[\%]$} & & \\
\hline$\%]$ & & & & \\
\hline
\end{tabular}

The utility maximizing

homo oeconomicus is a distorted picture of reality and $5 \quad 27$

$27 \quad 32$

35

1 therefore useless.

Table 3 shows the respondents' answers regarding the relevance of the homo oeconomicus. The majority of the German economists still think of the homo oeconomicus as a useful concept. 
Table 4. Nature of scientific work

\begin{tabular}{llll}
\hline & $\begin{array}{l}\text { Mainly theo- } \\
\text { retical (pure } \\
\text { research) [\%] }\end{array}$ & $\begin{array}{l}\text { Mainly empiri- } \\
\text { cally orientated } \\
{[\%]}\end{array}$ & $\begin{array}{l}\text { Aiming at pol- } \\
\text { icy advice [\%] }\end{array}$ \\
\hline $\begin{array}{l}\text { How would you characterize your } \\
\text { scientific work? }\end{array}$ & 34 & 36 & 30 \\
\hline
\end{tabular}

Note: Table 4 shows the respondents' answers to the nature of their scientific work.

Multiple answers were possible. One third seems to work mainly theoretical, one third mainly empirically orientated and one third aiming at giving policy advice.

Table 5. Agreement on fundamental issues

\begin{tabular}{lllll}
\hline & $\begin{array}{l}\text { Generally } \\
\text { Agree [\%] }\end{array}$ & $\begin{array}{l}\text { Agree with } \\
\text { Provisions } \\
{[\%]}\end{array}$ & $\begin{array}{l}\text { Generally } \\
\text { Disagree } \\
{[\%]}\end{array}$ & $\begin{array}{l}\text { No Answer } \\
{[\%]}\end{array}$ \\
\hline $\begin{array}{l}\text { Economists agree on } \\
\text { fundamental issues. }\end{array}$ & 15 & 42 & 42 & 1 \\
\hline
\end{tabular}

Note: Table 5 shows German economists' views on their agreement on fundamental issues. The respondents think that there is not much agreement on fundamental issues among their colleagues.

Table 6. Role models

\begin{tabular}{ll}
\hline & Yes [\%] \\
\hline Would you regard yourself as someone's disciple? & 40 \\
$\begin{array}{l}\text { Did you have any scientific role models over the course of your scientific } \\
\text { career? }\end{array}$ & 48 \\
\hline
\end{tabular}

Note: Table 6 shows results on the relevance of role models in economics among German economists. Almost half of the respondents admit to having (had) role models over the course of their scientific career. Role models seem to play a major role in economics.

Table 7. Important economists 


\begin{tabular}{llll}
\hline $\begin{array}{l}\text { How important is the contribu- } \\
\text { tion of the following econo- } \\
\text { mists for today's economy? }\end{array}$ & $\begin{array}{l}\text { Very/Moderately } \\
\text { Important [\%] }\end{array}$ & $\begin{array}{l}\text { Rather Unimpor- } \\
\text { tant/ } \\
\text { Unimportant [\%] }\end{array}$ & $\begin{array}{l}\text { Don't Know } \\
{[\%]}\end{array}$ \\
\hline Paul Samuelson & 87 & 10 & 2 \\
John Maynard Keynes & 85 & 13 & 2 \\
Milton Friedman & 84 & 11 & 4 \\
Joseph Stiglitz & 82 & 13 & 5 \\
Paul Krugman & 77 & 15 & 8 \\
Gary Becker & 77 & 14 & 9 \\
Friedrich von Hayek & 74 & 21 & 5 \\
James Buchanan & 71 & 19 & 10 \\
Amartya Sen & 68 & 18 & 14 \\
Gerard Debreu & 60 & 25 & 15 \\
Jean Tirole & 60 & 19 & 21 \\
Douglas North & 53 & 23 & 23 \\
Daniel Kahneman & 53 & 19 & 27 \\
Walter Eucken & 52 & 37 & 10 \\
Andrei Shleifer & 43 & 27 & 31 \\
Ludwig Erhard & 24 & 70 & 6 \\
\hline
\end{tabular}

Note: Table 7 shows which economists' contributions are seen as important for today's economy. The choice of economists was given to the respondents. 
Table 8. What makes a good economist?

\begin{tabular}{|c|c|c|c|c|}
\hline $\begin{array}{l}\text { What makes a good economist? } \\
\text { What puts someone on the fast } \\
\text { track? }\end{array}$ & $\begin{array}{l}\text { Very Important } \\
{[\%]}\end{array}$ & $\begin{array}{l}\text { Moderately } \\
\text { Important [\%] }\end{array}$ & $\begin{array}{l}\text { Unimportant } \\
{[\%]}\end{array}$ & $\begin{array}{l}\text { Don't Know } \\
{[\%]}\end{array}$ \\
\hline \multirow{6}{*}{$\begin{array}{l}\text { Being very knowledgeable } \\
\text { about one particular field }\end{array}$} & \multicolumn{4}{|c|}{ German economists 2006: } \\
\hline & 76 & 23 & 1 & 0 \\
\hline & \multicolumn{4}{|c|}{ European graduate students 2005/6: } \\
\hline & 35 & 48 & 14 & 3 \\
\hline & \multicolumn{4}{|c|}{ US professionals 2002: } \\
\hline & 35 & 46 & 17 & 2 \\
\hline \multirow{6}{*}{$\begin{array}{l}\text { Being interested in, and good at } \\
\text { empirical research }\end{array}$} & \multicolumn{4}{|c|}{ German economists 2006: } \\
\hline & 59 & 36 & 4 & 0 \\
\hline & \multicolumn{4}{|c|}{ European graduate students 2005/6: } \\
\hline & 38 & 51 & 9 & 2 \\
\hline & \multicolumn{4}{|c|}{ US professionals 2002: } \\
\hline & 46 & 39 & 11 & 4 \\
\hline \multirow{6}{*}{$\begin{array}{l}\text { A broad knowledge of the eco- } \\
\text { nomic literature }\end{array}$} & \multicolumn{4}{|c|}{ German economists 2006: } \\
\hline & 54 & 41 & 4 & 0 \\
\hline & \multicolumn{4}{|c|}{ European graduate students $2005 / 6$ : } \\
\hline & 16 & 53 & 28 & 3 \\
\hline & \multicolumn{4}{|c|}{ US professionals 2002: } \\
\hline & 24 & 39 & 35 & 2 \\
\hline \multirow{6}{*}{$\begin{array}{l}\text { A thorough knowledge of the } \\
\text { economy }\end{array}$} & \multicolumn{4}{|c|}{ German economists 2006: } \\
\hline & 48 & 42 & 9 & 1 \\
\hline & \multicolumn{4}{|c|}{ European graduate students $2005 / 6$ : } \\
\hline & 16 & 39 & 42 & 4 \\
\hline & \multicolumn{4}{|c|}{ US professionals 2002: } \\
\hline & 28 & 35 & 24 & 13 \\
\hline \multirow{6}{*}{$\begin{array}{l}\text { Being smart in the sense of be- } \\
\text { ing good at problem solving }\end{array}$} & \multicolumn{4}{|c|}{ German economists 2006: } \\
\hline & 45 & 45 & 9 & 2 \\
\hline & \multicolumn{4}{|c|}{ European graduate students $2005 / 6$ : } \\
\hline & 61 & 34 & 6 & 0 \\
\hline & \multicolumn{4}{|c|}{ US professionals 2002: } \\
\hline & 67 & 28 & 2 & 2 \\
\hline \multirow{6}{*}{ Excellence in mathematics } & \multicolumn{4}{|c|}{ German economists 2006: } \\
\hline & 25 & 67 & 8 & 1 \\
\hline & \multicolumn{4}{|c|}{ European graduate students 2005/6: } \\
\hline & 40 & 51 & 9 & 0 \\
\hline & \multicolumn{4}{|c|}{ US professionals 2002: } \\
\hline & 22 & 59 & 17 & 2 \\
\hline \multirow{6}{*}{$\begin{array}{l}\text { Ability to make connections } \\
\text { with prominent professors }\end{array}$} & German econom & ts 2006: & & \\
\hline & 7 & 37 & 50 & 6 \\
\hline & European gradu & students 2005 & & \\
\hline & 30 & 54 & 11 & 5 \\
\hline & US professional & 2002: & & \\
\hline & 17 & 46 & 30 & 7 \\
\hline
\end{tabular}

Note: Table 8 shows assumed key factors of success for German economists, European graduate students and US professionals (Colander 2008). The latter were asked "What puts someone on the fast track in their jobs?" American graduate students were asked "What puts someone on the fast track in graduate school. European economists were asked: "What makes a good economist?" 


\section{Appendix}

The following tables report the marginal effects and the corresponding statistical significance levels (with $* * *$ statistically significant at the $99.9 \%$ level, $* *$ statistically significant at the $99 \%$ level, * statistically significant at the $95 \%$ level, and (*) statistically significant at the $90 \%$ level) for four determinants (profession, age, gender and political orientation) in a jointly estimated multiple probit analysis of the nine tables reported in the text. The variable "Prof. Assist." is positive when the respondent is a professor or a scholar at a scientific institution. The variable "Age" has 3 categories, respondents under 35 , respondents of age 35 to 55, and respondents over 55. The category "Women" is positive when the respondent is a woman, the category "Liberal" is positive when the respondent sympathizes with the Free Democratic Party FDP.

The marginal effects may be interpreted the following way: the first coefficient in Table $1 \mathrm{~A}$ indicates an increase in the probability of supporting the Neoclassical Theory by 0.1641 for an instantaneous change in the variable "Prof. Assist." with all other variables (age, women and political orientation) held at their mean. Another way to put it (for variables with only two values such as Prof. Assist., Women and Liberal): being a professor or assistant at a scientific institution (rather than having a job outside a scientific institution) increases the probability of supporting Neoclassics by 0.1641 when answering to the question: "Considering your scientific attitude, which school of thought do you prefer?", holding all other variables at their mean. This higher support is statistically significant at the $99 \%$ level.

For the category age (which can take on three values: under 35, between 35 und 55, and over 55) the marginal effect means the change in the probability of supporting the 
corresponding question for an instantaneous change in age. For a German economist who is average in all characteristics, an instantaneous change in age decreases his/her probability to find Neoclassical Theory important for the solution of current political and economic problems by -0.1020 (see Table $2 \mathrm{~A}$ ). This decreasing support is statistically significant at the $99.9 \%$ level.

The second table takes a closer look at the marginal effects on the support to Ordo-Liberalism as a school of thought and the support of the homo oeconomicus depending on a change in age. Here, the variable "Age" is split into the two variables "Age $<35$ " and "Age $>55$ ". Non-linear dependencies on age can thus be revealed. The table can be interpreted as follows: The fact of being an economist over 55 (compared to being younger than 55) increases the probability of supporting Ordo-Liberalism as a school of thought by 0.1424 , holding other variables at their means. This increasing support is statistically significant at the $95 \%$ level. 


\section{Multiple probit analysis I}

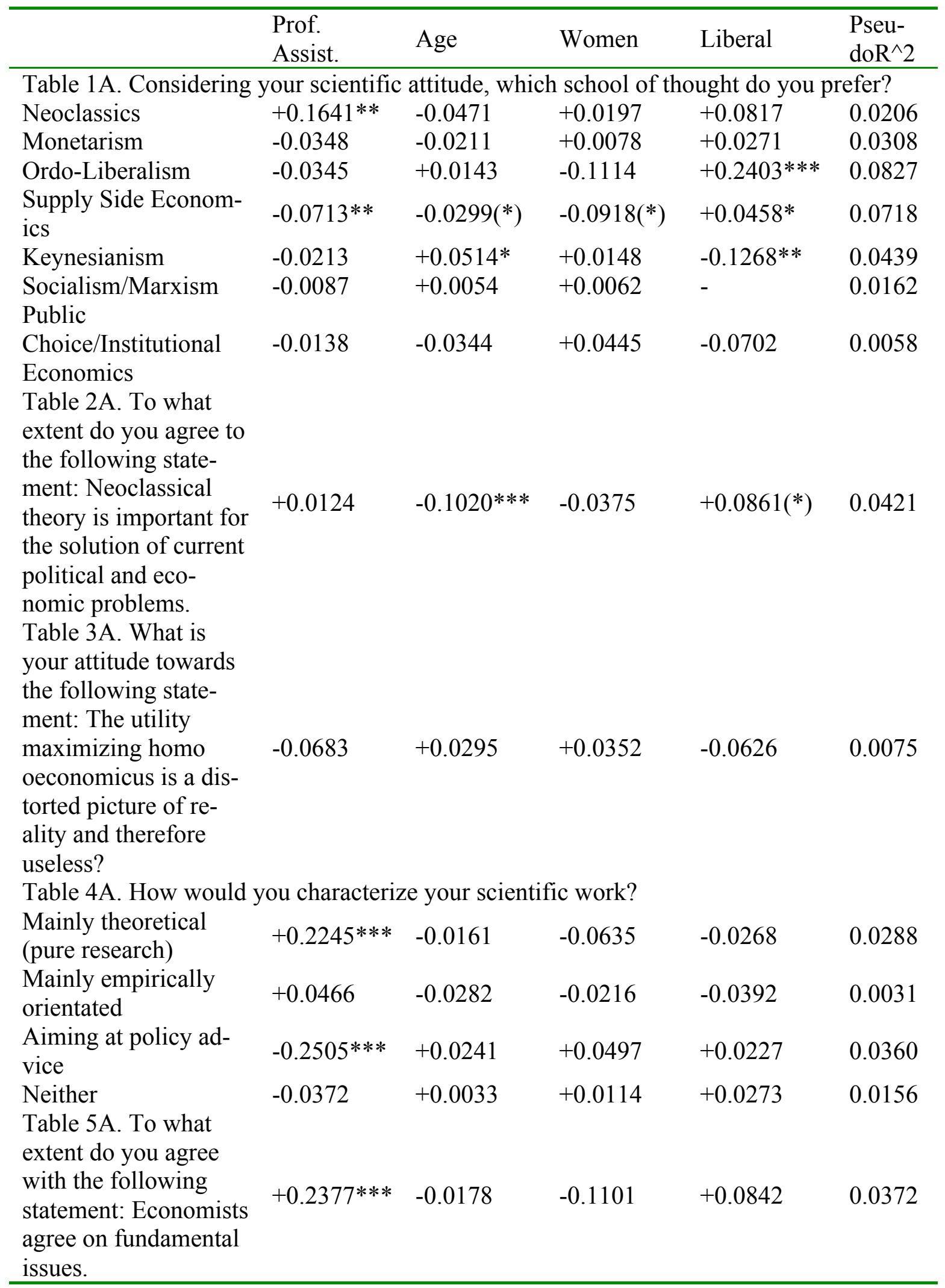




\begin{tabular}{|c|c|c|c|c|c|}
\hline & $\begin{array}{l}\text { Prof. } \\
\text { Assist. }\end{array}$ & Age & Women & Liberal & $\begin{array}{l}\text { Pseu- } \\
\text { doR^2 }\end{array}$ \\
\hline $\begin{array}{l}\text { Table 6A. Would you } \\
\text { regard yourself as } \\
\text { someone's disciple? }\end{array}$ & +0.0317 & $+0.1780 * * *$ & +0.0591 & -0.0185 & 0.0419 \\
\hline $\begin{array}{l}\text { Did you have any sci- } \\
\text { entific role models } \\
\text { over the course of } \\
\text { your scientific career? }\end{array}$ & +0.0307 & $+0.1274 * * *$ & -0.0427 & +0.0708 & 0.0250 \\
\hline \multicolumn{6}{|c|}{$\begin{array}{l}\text { Table 7A. How important is the contribution of the following economists for today's ec- } \\
\text { onomy? }\end{array}$} \\
\hline Paul Samuelson & $+0.0606(*)$ & -0.0175 & +0.0186 & -0.0410 & 0.0219 \\
\hline John Maynard Keynes & +0.0333 & +0.0209 & +0.0794 & $-0.1036 * *$ & 0.0365 \\
\hline Milton Friedman & +0.0230 & $-0.0551 *$ & +0.0408 & $+0.1538 * * *$ & 0.0743 \\
\hline Joseph Stiglitz & +0.0158 & $-0.0522 *$ & +0.0865 & -0.0219 & 0.0259 \\
\hline Paul Krugman & $-0.2219 * * *$ & -0.0226 & +0.0706 & -0.0430 & 0.0522 \\
\hline Gary Becker & -0.0326 & $-0.0733 *$ & -0.0268 & $+0.1042 *$ & 0.0362 \\
\hline Friedrich von Hayek & -0.0244 & +0.0309 & $+0.1441\left(^{*}\right)$ & $+0.1314 * *$ & 0.0259 \\
\hline James Buchanan & -0.0600 & +0.0295 & +0.1180 & +0.0442 & 0.0143 \\
\hline Amartya Sen & +0.0626 & +0.0299 & +0.0169 & -0.0583 & 0.0105 \\
\hline Gerard Debreu & $+0.1346^{*}$ & $-0.1612 * * *$ & -0.0146 & -0.0353 & 0.0580 \\
\hline Jean Tirole & +0.0938 & $-0.0782^{*}$ & +0.0917 & +0.0712 & 0.0284 \\
\hline Douglas North & -0.0823 & $+0.0842 *$ & -0.0256 & -0.0040 & 0.0150 \\
\hline \multirow{2}{*}{$\begin{array}{l}\text { Daniel Kahneman } \\
\text { Walter Eucken }\end{array}$} & +0.0026 & $-0.1022 * *$ & -0.0743 & -0.0208 & 0.0220 \\
\hline & $-0.1408^{*}$ & $+0.0931 *$ & $\begin{array}{l}+0.2959 * * \\
*\end{array}$ & +0.0069 & .0420 \\
\hline \multirow{2}{*}{$\begin{array}{l}\text { Andrei Shleifer } \\
\text { Ludwig Erhard }\end{array}$} & -0.0414 & $-0.1333 * *$ & +0.0193 & $+0.1176\left(^{*}\right)$ & 0.0292 \\
\hline & +0.0396 & +0.0259 & $\begin{array}{l}+0.3167 * * \\
*\end{array}$ & +0.0614 & 0.0557 \\
\hline \multicolumn{6}{|c|}{ Table 8A. What makes a good economist? } \\
\hline $\begin{array}{l}\text { Being good at manag- } \\
\text { ing and problem } \\
\text { solving }\end{array}$ & +0.0024 & -0.0055 & +0.0547 & $+0.0659(*)$ & 0.0183 \\
\hline $\begin{array}{l}\text { Excellence in math- } \\
\text { ematics }\end{array}$ & $+0.0520^{*}$ & +0.0019 & $+0.0893(*)$ & +0.0076 & 0.0335 \\
\hline $\begin{array}{l}\text { Being very know- } \\
\text { ledgeable about one } \\
\text { particular field }\end{array}$ & +0.0023 & $+0.0113(*)$ & - & -0.0029 & 0.1070 \\
\hline $\begin{array}{l}\text { Ability to make con- } \\
\text { nections with promi- } \\
\text { nent professors }\end{array}$ & +0.0529 & -0.0148 & +0.0694 & -0.0621 & 0.0058 \\
\hline $\begin{array}{l}\text { Being interested in, } \\
\text { and good at, empirical } \\
\text { research }\end{array}$ & -0.0127 & -0.0117 & +0.0378 & +0.0281 & 0.0231 \\
\hline $\begin{array}{l}\text { Having a wide know- } \\
\text { ledge of the economic }\end{array}$ & +0.0034 & +0.0105 & +0.0342 & -0.0123 & 0.0128 \\
\hline
\end{tabular}




\begin{tabular}{llllll}
\hline & $\begin{array}{l}\text { Prof. } \\
\text { Assist. }\end{array}$ & Age & Women & Liberal & $\begin{array}{c}\text { Pseu- } \\
\mathrm{doR}^{\wedge} 2\end{array}$ \\
\hline $\begin{array}{l}\text { literature } \\
\begin{array}{l}\text { Having a thorough } \\
\text { knowledge of the ec- } \\
\text { onomy }\end{array}\end{array}$ & -0.0063 & +0.0331 & +0.0537 & $-0.0659^{*}$ & 0.0337 \\
\hline
\end{tabular}




\section{Multiple probit analysis II}

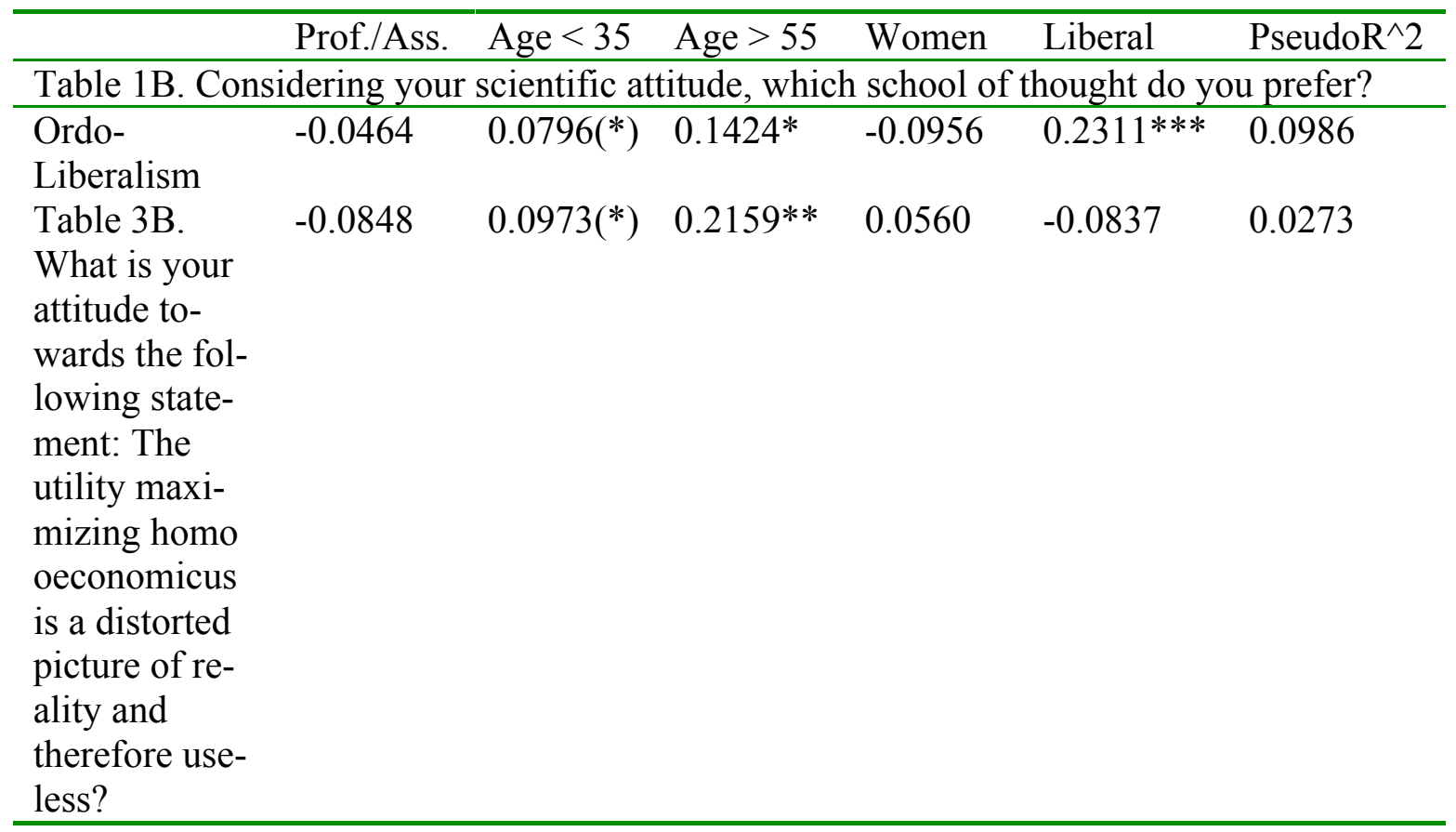

${ }^{1}$ e.g. Colander and Klamer 1987; Klamer and Colander 1990; Hansen 1991; Krueger 1991; Colander 2005, 2007.

${ }^{2}$ e.g. Kolm 1988; Frey and Eichenberger 1992, 1993; Forte 1995; van Dalen and Klamer 1997; Colander 2008.

${ }^{3}$ e.g. Kearl, Pope, Whiting and Wimmer 1979; Frey, Pommerehne, Schneider and Gilbert 1984; Alston, Kearl and Vaughan 1992; Schelling 1995; Mayer 2001; Frey, Humbert and Schneider 2007.

${ }^{4}$ These are: 1) spending money in a way that, from the standpoint of the average taxpayer, is foolish, but that benefits a particular group; 2) fixing prices above equilibrium; and 3) obtaining cartel profits by restricting entry into a business.

${ }^{5}$ Looking at how the views of the former American graduate students changed over the years, it can be seen that excellence in mathematics is valued less and empirical research is valued more. "Problem-solving.." however continues to be the most important key factor for success in their opinion. "Having a thorough knowledge of the economy" and "Having a broad knowledge of the economics literature", two factors that had been valued very poorly by the American graduate students in the early 1980 s, are taken to be more important of the older respondents. Nevertheless these factors are still much less important for US respondents than for German economists.

${ }^{6}$ The question in the survey for the German economists was (slightly) different from the question the European graduate students and US professionals were asked. While the latter were asked "Which characteristics will most likely place someone on the fast track in graduate school/their jobs?", German economists were asked "What makes a good economist?" Thus, German economists might have thought about success factors throughout their whole life as an economist whereas European graduate students must have been focussed on the success while being in graduate school. It can, moreover, not be excluded that the German economists surveyed may have understood the question in a normative sense, responding to which characteristics should make an economist successful.

${ }^{7}$ Five schools (London School of Economics, Stockholm School of Economics, Universität Bonn, Université Catholique de Louvain and Universitat Pompeu Fabra) were taken into account.

${ }^{8}$ Thorough knowledge of the economy (38\% Very important, $40 \%$ Moderately important, $16 \%$ Unimportant, $7 \%$ Don't know), Having a wide knowledge of the economics literature (48\% Very impor- 
tant, 35\% Moderately important, 14\% Unimportant, 3\% Don't know), Being smart and good at problem solving (56\% Very important, 34\% Moderately important, $8 \%$ Unimportant, 2\% Don't know).

${ }^{9}$ The option provided in the questionnaire for German economists was slightly different: "Being good at managing and problem solving." It should be taken into account that, for German economists, "problem solving" does not necessarily mean assignments. 